\title{
Stories of Our Fellow Mathematics Tutors during Covid-19 Pandemic
}

\author{
Muhammad Taqiyuddin \\ Department of Mathematics, University of Auckland, mtaq594@aucklanduni.ac.nz \\ Faliqul Jannah Firdausi \\ SMA Negeri 15 Bandung, faliqul.firdausi@gmail.com \\ Mohamad Tri Afriyadi Nur Asidin \\ SMA Kuntum Cemerlang, triafriyadi@gmail.com
}

\begin{abstract}
The tutoring phenomenon has been discussed from multiple angles. Sometimes, math tutors, as part of the tutoring system, are framed as the contributors of shadow education and the parasite of the national educational system. We claim that some math tutors are financially vulnerable. Our paper serves to bring new nuances into the complexity of being math tutors during the Covid-19 pandemic time. In doing so, we employed the qualitative study method by elaboratively interviewing five Indonesian mathematics tutors during September 2021. Specifically, this article focused on three aspects related to math tutoring: challenges, adaptations, and success. By listening to their stories, we gained some insights. First, tutors who were struggling the most are the ones who come from a poor background and who work for middle-low-income students. Second, the cost of adapting to the new work environment as math tutors need to upgrade their devices is one of the contributing factors in transitioning from offline tutoring to online tutoring. Third, those who thrived are the ones who are familiar with online tutoring, already have decent devices which are sufficient for heavy online multi-tasking work, and are in the circle of upper-middle-income families. In retrospect, this research not only sheds light on social issues in our educational system but also raised some key practical issues of teaching mathematics online which may affect tutors with various backgrounds differently. All in all, our research is part of our endeavor to fight for math tutors' welfare.
\end{abstract}

Keywords: mathematics tutors, tutoring, online tutoring

\section{ABSTRAK}

Fenomena bimbingan belajar telah dibahas dari berbagai sudut pandang. Terkadang, tutor matematika, sebagai bagian dari sistem bimbingan belajar, dipandang sebagai penyumbang pendidikan bayangan dan parasit sistem pendidikan nasional. Kami mengklaim bahwa beberapa tutor matematika rentan secara finansial. Artikel kami hadir untuk menghadirkan nuansa baru dalam kompleksitas menjadi tutor matematika di masa pandemi Covid-19. Dalam melakukannya, kami menggunakan metode studi kualitatif dengan mewawancarai lima tutor matematika Indonesia secara elaboratif selama September 2021. Secara khusus, artikel ini berfokus pada tiga aspek terkait bimbingan belajar matematika: tantangan, adaptasi, dan kesuksesan. Dengan mendengarkan cerita mereka, kami memperoleh beberapa wawasan. Pertama, tutor yang paling kesulitan adalah mereka yang berasal dari latar belakang miskin dan bekerja untuk siswa berpenghasilan menengah ke bawah. Kedua, biaya beradaptasi dengan lingkungan kerja baru karena tutor matematika perlu memperbarui perangkat mereka adalah salah satu faktor yang berkontribusi dalam transisi dari les luring ke les daring. Ketiga, mereka yang sukses adalah mereka yang terbiasa dengan bimbingan belajar online, sudah memiliki perangkat yang layak yang cukup untuk pekerjaan multi-tasking online yang berat, dan berada di kalangan keluarga berpenghasilan 
menengah ke atas. Dalam retrospeksi, penelitian ini tidak hanya menyoroti masalah sosial dalam sistem pendidikan kita, tetapi juga mengangkat beberapa masalah praktis utama dari pengajaran matematika online yang dapat mempengaruhi tutor dengan berbagai latar belakang secara berbeda. Secara keseluruhan, penelitian kami adalah bagian dari upaya kami untuk memperjuangkan kesejahteraan tutor matematika.

Kata Kunci: tutor matematika, les, les daring.

\section{INTRODUCTION}

The worldwide phenomenon of tutoring has been scrutinized from multiple angles by researchers and received mixed responses from different countries. One angle can be at a macro level. For instance, some researchers discussed the phenomenon from an economic perspective as well as policy makers' point of view (Entrich, 2020; Jayachandran, 2014; Dang \& Rogers, 2008; Dawson, 2010; Silova \& Budiene, 2006; Silova, 2010). These types of research are crucial for those who are in power to have foundations for regulating national education. Another angle can be at a micro-level. Some researchers vowed the benefits of tutoring such as increasing students' final grades (e.g., Rickard \& Mills, 2018; Berberoğlu \& Tansel, 2014) and enhancing students' interaction (e.g., Chi et al., 2001). Meanwhile, different countries vary in how they responded to the tutoring phenomenon (Dang \& Rogers, 2008). One of the arguments of those who are against tutoring is that it is a parasite of the national education system. This means that tutoring is taking the advantage of the broken educational systems to gain economic capital instead of healing it. Regarding this issue, Silova (2010) stated, "many high school students reportedly stop going to school during the last couple of months before university entrance examinations, and instead attend private tutoring lessons and preparatory courses" (p. 335). This fact proves that tutoring can be problematic and thus we may say that tutors are responsible for the problem.

Because tutors are at the heart of the tutoring system, tutors could be seen as the contributors of shadow education and the parasite of the national educational system. Let's attend to the notion of shadow and parasite first. Stevenson and Baker (1992) explained shadow education as "a set of educational activities that occur outside formal schooling and are designed to enhance the student's formal school career" (p. 1639). Meanwhile, parasite here means something that disrupts the effort of the national curriculum. Teachers' involvement in shadow and parasite education can be seen in previous studies. For instance, Silova et al. (2006) stated, "In the context of market-driven reforms, many teachers have eagerly adopted the logic of "service provision," using private tutoring as a key income-generation activity" (p. 48). However, in our opinion, viewing tutors as a parasite of the national curriculum is not always true. We argue that some tutors are not the ones who benefit the most despite being in the system, they are rather the vulnerable ones. Our stance is in line with Natasha et al.'s (2021) view, "It is therefore observed that although there is an increase in the demand for shadow education in Greece at the time of the economic crisis, the working conditions of the tutors have worsened" (p. 314). In the case of Indonesia, some honorary teachers are doing tutoring to economically survive because of the small amount of money the honorary teachers got from teaching (Sulisworo, et al., 2017). This phenomenon got worsened by the Covid-19 pandemic. 
The Covid-19 pandemic does not only affect society in people's mobility, economy, and health, but it also has a serious impact on education internationally (see Oliveira et al., 2021; Reimers, 2021; Krause et al., 2021). Tutors have also suffered from it (Reimers, 2021; Lantsoght, et al., 2021). However, by scanning some major journals in mathematics education (Williams \& Leatham, 2017), we could not find articles that focus on Covid-19 effects on mathematics tutors. In this paper, we aim to fill this gap by focusing on the people, the math tutors, who are affected by the pandemic. We are interested in how these individuals survived during the pandemic so far. Moreover, we have seen a growing research trend in mathematics education focusing on social issues which can be seen in the two major mathematics education journals, namely Journal for Research in Mathematics Education and Educational Studies in Mathematics (Williams \& Leatham, 2017). The issues include inequalities in mathematics education, racial issues, and teachers' welfare (e.g. Leyva, 2021; Joseph, et al., 2021; Wu \& Battey, 2021; Maloney \& Matthews, 2020; Yılmaz, et al., 2021; Matthews, et al., 2021; Allen \& Trinick, 2021). Thus, we aim to follow this trend and continue the endeavor to understand and speak for those who are affected by social inequalities. In this study, we limit our participants to mathematics tutors in Indonesia.

Therefore, in this paper, we present to you research insights from having conversations with five mathematics tutors in Indonesia. Within this conversation, we investigated how they navigated their work during this pandemic time. We also probed what are the struggles and the success. By hearing their voices, we aim to contribute to the landscape of literature on the math tutoring phenomenon as well as the social inequalities spectrum. As a disclaimer, most of our finding in this article was presented at The Third Ahmad Dahlan International Conference on Mathematics and Mathematics Education (3rd ADINTERCOMME) 2021.

\section{METHOD}

We had conversations with five teachers whose details can be found in Table 1. All the names presented here are pseudonyms. While making sure our participants were engaging in tutoring during the Covid-19 time, they were chosen based on acquaintance and availability for our convenience. Our choice of the case study approach was because our aim was not to give the readers an exhaustive presentation of how the tutoring system worked during the pandemic in Indonesia. Rather, we focus on telling the readers important insights from the struggles and successes of our participants.

Table 1. Participants of the Study

\begin{tabular}{cccc}
\hline Name (Gender) & Geographical Information & Duration & Interviewer \\
\hline Dewi (Female) & Purwakarta, Jawa Barat & 16 minutes & 3rd Author \\
Raisa (Female) & Bandung, Jawa Barat & 18 minutes & 3rd Author \\
David (Male) & Bandung, Jawa Barat & 10 minutes & 3rd Author \\
Santi (Female) & Bukittinggi, Sumatra & 27 minutes & 2nd Author \\
Ana (Male) & Bandung, Jawa Barat & 42 minutes & 2nd Author \\
\hline
\end{tabular}


Furthermore, we followed a qualitative study approach by employing a semi-structured interview (Saldaña, 2013). The interviews were undertaken by the second author and the third author using Zoom during September 2021. Our interviews were guided by two guiding questions: 1) What are the challenges that you are facing during the pandemic? and 2) How did you adapt during the transition from before pandemic to a pandemic? In doing so, we asked follow-up questions to explore more stories because the nature of this research is exploratory.

In analyzing the data, we followed Saldana's (2016) qualitative coding workflow. First, all authors listened to the recording. Through several online meetings, we discussed our takeaways from the recordings in several rounds. Based on these discussions, we draw themes and discussed them thoroughly. We argued for our interpretation of the data and then revised our themes based on the discussion. We employed this method for several rounds. We pay attention to details, word by word to understand their intention from the utterances in the transcript.

\section{RESULT AND DISCUSSION}

In discussing the findings, we use three themes that emerged from our discussion: challenges, adaptations, and success. Under these three categories, we will highlight a number of issues we identified from our data. However, before describing these categories, we will present a snapshot of our participants' conditions during the pandemic tutoring work in Table 2. We want to highlight that most of our participants are coming from upper-middle-income families and work at the same level. Most of them experienced a decreasing number of students and used laptops as a primary tool for tutoring.

Table 2. The Overview of Participants' Circumstances

\begin{tabular}{|c|c|c|c|c|c|}
\hline $\begin{array}{l}\text { Tutor } \\
\text { name }\end{array}$ & $\begin{array}{c}\text { Tutor's } \\
\text { Economic } \\
\text { Background }\end{array}$ & $\begin{array}{l}\text { Tools used for } \\
\text { tutoring }\end{array}$ & $\begin{array}{l}\text { The trend of } \\
\text { tutored students }\end{array}$ & $\begin{array}{l}\text { Technical } \\
\text { Challenges }\end{array}$ & $\begin{array}{c}\text { Students' } \\
\text { Economic } \\
\text { Background }\end{array}$ \\
\hline Dewi & $\begin{array}{l}\text { Upper-middle } \\
\text { income family }\end{array}$ & $\begin{array}{l}\text { Touchscreen } \\
\text { laptop, stylus }\end{array}$ & Increasing & $\begin{array}{l}\text { Familiarizing } \\
\text { with a new } \\
\text { setup } \\
\text { Adapting with }\end{array}$ & $\begin{array}{l}\text { Upper-middle } \\
\text { income family }\end{array}$ \\
\hline Raisa & $\begin{array}{l}\text { Upper-middle } \\
\text { income family }\end{array}$ & Laptop, pen-tab & Decreasing & $\begin{array}{l}\text { several online } \\
\text { learning } \\
\text { setups }\end{array}$ & $\begin{array}{l}\text { Upper-middle } \\
\text { income family }\end{array}$ \\
\hline David & $\begin{array}{l}\text { Upper-middle } \\
\text { income family }\end{array}$ & $\begin{array}{l}\text { Laptop, physical } \\
\text { board, and pen, } \\
\text { phone }\end{array}$ & Increasing & $\begin{array}{l}\text { Familiarizing } \\
\text { with new } \\
\text { applications }\end{array}$ & $\begin{array}{l}\text { Upper-middle } \\
\text { income family }\end{array}$ \\
\hline Santi & $\begin{array}{l}\text { Upper-middle } \\
\text { income family }\end{array}$ & Laptop & Decreasing & $\begin{array}{l}\text { Not owning a } \\
\text { proper device }\end{array}$ & $\begin{array}{l}\text { Upper-middle } \\
\text { income family }\end{array}$ \\
\hline Ana & $\begin{array}{l}\text { Lower-middle } \\
\text { income family }\end{array}$ & Laptop & Decreasing & $\begin{array}{l}\text { Not owning a } \\
\text { proper device }\end{array}$ & $\begin{array}{l}\text { Lower-middle } \\
\text { income family }\end{array}$ \\
\hline
\end{tabular}

\section{Challenges}

Among our participants, tutors who were struggling the most are the ones who come from a poor background and who work for lower-middle-income students. This phenomenon raises one of the crucial issues we encountered in our data which is disadvantaged tutors because the talk about 'disadvantage' usually come with students not with teachers or tutors as can be found in some studies (Mullen et al., 2021; Yılmaz et al., 2021; Silova \& Budiene, 2006). The talk about disadvantaged tutors is rarely found in the literature. We were able to see this issue through one of our participants, 
Ana, who is coming from a non-wealthy family. For instance, she had to take care of her family members. The decrease of the costumers is not only faced by her. However, the struggle faced by her is not like the others. Let's look at the case of Ana and Santi. Both told us that the decrease of their students was more than $50 \%$. Specifically, Ana told us, "In the earlier time of the pandemic. There was no one whom I tutored. For how long? It is quite significant. It is about one or two months." However, later, Ana was still struggling to get her students back while Santi got students from a tutoring institution she works for.

Furthermore, what distinguished her case from the other participants' cases in which income decrease also occurred was the ability to gain back the customers. Our argument for this is that at the beginning of Covid-19, people were not used to online learning. It is also the case that only students who can afford the technology necessary for online learning are eager and able to do online tutoring. In the case of Ana, even after two months of Covid-19, only one student from 5 students that she originally taught came for tutoring in offline mode. Another argument is because of the economic status of her students as told by Mullen et al. (2021) that "socio-economically disadvantaged students suffer substandard learning outcomes when studying online" (p. 334). Another study was done by Yllmaz et al. (2021) also confirms that "The teachers' perspectives identified that during remote instruction, most of the students who were disadvantaged economically, culturally, and linguistically experienced a wider learning gap due to a lack of access to the Internet and television" (p. 19). This is why Silova and Budiene (2006) strongly support "Ensuring private tutoring opportunities for the disadvantaged students (whether they are in the capital or a more remote region) would be fair to everyone, rather than ones in particular locations" (p. 253).

The struggle that Ana faced did not end there. In order to catch up with high-tech workflow in online teaching, she was thinking twice about purchasing a decent device necessary for better digital writing. Specifically, he told us about her considering buying a pen-tab device, but she decided not to because according to her, it was not an easy financial decision. This particular finding resonates well with Mullen et al. (2021) regarding the issue of the physical act of writing mathematical symbols and narratives as they said, "As time progressed, it was evident that tutors, in particular, became more equipped with the requisite technologies (tablet, stylus, etc.) to mitigate these issues but not every student had such luxuries" (p. 344). Specific to tablets, previous studies perceive this tool as an important part of teachers' work (e.g., Cárdenas et al., 2021; Heraty et al., 2021) and. This scenario was not the case for other participants. We believe that what happened to Ana is because of the financial problem is that she was concerned about how little the salary was for a guru honorer (honorary teachers), a term for teachers who are not hired by the government but work in school. She said, "Why is it (the salary) not the same as others, at least at the level of the regional minimum monthly wage." From this utterance, we learn that the cost of purchasing matters. We barely found explicit mention about this except Drijvers et al., (2021) have a similar concern by mentioning "teachers' time and attention at the cost of using specific mathematical tools" (p. 55).

All in all, we learn through our interaction with the tutors that inequalities in mathematics education do not only apply to students but also to mathematics tutors echoing previous studies (see Mullen et al., 2021; Yılmaz et al., 2021; Joseph et al. 2021; Silova \& Budiene, 2006). This inequality 
impacts the opportunities that a teacher may get for just only teaching. Moreover, the case of Ana enabled us to see how vulnerable it is for tutors who cannot afford the cost of technology necessary for heavy-duty workflow in an online setting. It is also apparent to us that the economic background of students who are taught by tutors contributes to the vulnerability of the tutors' incomes.

Adaptation

Our second theme is the adaptations that math tutors pursued in the attempts to transition from offline learning into online learning. The previous study such as Heraty (2021) considered this adaptation as including exploration of technology. Another study by Johns and Mills (2021) mentioned that tutors are better to be familiar with the online system and be aware of students' needs of both synchronous and asynchronous modes. Moreover, König et al. (2020) asserted that "Findings from regression analyses show that information and communication technologies (ICT) tools, particularly digital teacher competence and teacher education opportunities to learn digital competence, are instrumental in adapting to online teaching during COVID-19 school closures" ( $p$. $608)$.

In our case, we found that the distinguishing features of teaching mathematics online contributed to the extra cost of adaptation. In other words, the cost of the technology needed in teaching math is one of the blocks in attempting to adapt to the new online work environment. For instance, in teaching mathematics, ideally, we need to do lecturing by explaining orally while also physically writing down the mathematics explanation. In order to do that in an online setting, preferably, we need a tab and a pen or a pen-tablet (a device that allows you to write down on the tablet with the pen by connecting the tablet to the laptop). Some also may use a pen that works on a touch-screen laptop. The cost of this kind of setup in both cases is not cheap for some. Again, in the case of Ana, she identified herself needing the pen-tablet setup and because she could not afford it, she was borrowing a pen-tablet from her friend. Another issue is the microphone in a laptop which might be not a significant feature for doing offline work. We rarely used that feature. However, in online teaching, we depend so much on a microphone because we mostly explain orally. Ana's laptop was the case where the microphone did not work properly. What happened to Ana is again an instance where we can see how inequality may contribute to inequality of opportunities the teaching and learning mathematics.

Let's take a look at our specific findings by contrasting the case of Ana with Dewi and David. Dewi already owns a decent device which is a touchscreen laptop and so, the only thing that she needed was a pen which did not cost that much compared to a pen and a tab. So, for her, the adaptation that she needed is familiarizing herself with the workflow of using a pen and her laptop in her teaching. A similar case we found in David. According to his story, the adaptation for him is with getting to know the applications needed to teach online like Zoom.

Regarding this finding, previous studies rarely talk about this specific cost of technologies that need to be considered by teachers as a personal budget. The available discussion of the cost of technologies is often situated within the school budget or governmental budget (see Reimers, 2021; Silova \& Budiene, 2006). However, we have seen some discussions of why online tutoring, tablets, and stylus, for example, are important. For instance, Heraty et al. (2021) stated "Without a tablet and 
stylus, writing with a mouse was difficult and quite slow, especially with legibility being so important" (p. 58). Thus, our findings shed new light on this nuance of how the cost of technologies hinders the opportunities of teaching (or tutoring in this specific case).

Another finding that we found is that we can get creative with our limitations in adapting to the new environment. The notion of being creative in circumventing the technical difficulties during online learning may be well endorsed by the national curriculum of Finland (Reimers, 2021). There is another way around teaching mathematics in online mode which depends on an electronic pen shown by David. Instead of using an electronic one, we can use a video feature to capture us orally explaining something and writing it down on a physical board. This kind of setup was the case for David. He used two devices. One device is for the voice and the other is for the video. This was done by David because his laptop's speaker was not properly working. Thus, David showed us how he was able to adapt to the limitation and this was possible partly because he was already used to teaching online.

\section{Success}

Through interaction with the five Indonesian math tutors, we were able to witness some success stories in addition to the struggles we have discussed so far. In a nutshell, those who thrived in online tutoring are the ones who are familiar with online tutoring, already have decent devices which are sufficient for heavy online multi-tasking work, and are in the circle of upper-middle-income families. Let us break down these three categories. First, the familiarity with an online platform for teaching helped tutors at least online teaching technicalities. We also conjecture that the fact that a tutor has been on the online platform for some time help him to find new students because words got to spread that he can handle the online tutoring. Regarding familiarity with technology, in previous studies, for instance, König et al. (2020) stated that familiarity with software resources was found to be advantageous for teachers. Second, a tutor who has the ability to purchase technology for work is an individual who has the privilege to teach online smoothly. We view this ability to purchase as an issue of affordability. In this regard, Soudien et al. (2021) vowed that the existing social context plays a big role in the impact of Covid-19 we are facing now including the infrastructure affordances. To us, this also includes the teaching infrastructure affordances at an individual level. Third, we cannot ignore that the demand for online tutoring is coming from the upper-middle income family and so, those who tutored them are likely to get the job. Based on previous studies, we can view this issue as an issue of learning affordability at a personal level (e.g., König et al., 2020) or an issue of opportunities to learn (e.g., Silova \& Budiene, 2006). We will use the case of David and Dewi to illustrate our claim.

David who got even more online tutoring students during the covid told us about his experience with online tutoring. He said, "Before Covid, I have double, both of them. So, there are offline and online. But, I had only one student in Lampung. The limitation was that I was not familiar with Zoom, so I was using Skype, Line, and WhatsApp. I used my own board and used my own device to do video-call directed to the board." Later, he told us that he got more students from various places in Indonesia. The fact that he was working in an international school, an Indonesian private school that 
incorporates English as the main communication, implied that he is in the circle of the upper-middle family. His background and his success support our claim before.

Meanwhile, in the case of Dewi, she did not have any online tutoring before. However, she has the privilege of affording a decent laptop having the touch screen feature. She then decided to buy a stylus pen as she described, "Previously, I only used PPT for teaching and then I browsed around and found a stylus pen. It is pleasure to use, then I bought it. After buying it and trying it, it is actually easier. I can directly hand write in paint. So, it is easier to teach online if it is like this. If I need a picture, I can just download it, and it is accurate." Similar to David, Dewi got many students online. The students that were coming to Dewi were called santri, those who are students in an Islamic dormitory school. She mentioned that these students whom she teaches are coming from a high economic status. Again, the case of Dewi also supports our claim before.

From these two cases, we make a claim about the conditions in which tutors might be able to thrive. These conditions we mentioned before are not meant to be the only factors that can contribute to the success of getting many students. However, what concerned us is the fact that we see how inequality plays a huge role in determining the prosperity of teachers. Our concern was how challenging it was for the poor tutors to be able to catch up with high-tech online math tutoring. This concern adds nuances to the common talk about educational inequality by which poor students often experience learning loss (see Reimers, 2021). If it was not math, maybe it is different, especially because of the nature of teaching mathematics using versatile writing tools. In retrospect, this research not only sheds light on social issues in our educational system but also raised some key practical issues of teaching mathematics online which may affect tutors with various backgrounds differently.

\section{CONCLUSION}

Here, we will lay out a bigger picture of what happened to some of our fellow mathematics tutors who belong to our community of mathematics education family. One issue is about the inequality in opportunities to learn and teach. By this article, we want to raise the issue of this unfortunate because we have seen that this pandemic and the technology widen the inequality of the opportunity to learn for poor students and opportunity to teach for poor tutors. When we are not in the pandemic era, the poor students still have the ability to afford mass tutoring. The poor tutors also have the privilege to teach students regardless they do not have decent devices. All in all, our research is part of our endeavor to fight for math tutors' welfare as well as the opportunities to teach and learn.

\section{REFERENCES}

Allen, P., \& Trinick, T. (2021). Agency-structure dynamics in an indigenous mathematics education community in times of an existential crisis in education. Educational Studies in Mathematics, 108(1), 351-368.

Berberoğlu, G., \& Tansel, A. (2014). Does private tutoring increase students' academic performance? Evidence from Turkey. International Review of Education, 60(5), 683-701.

Cárdenas, S., Lomelí, D., \& Ruelas, I. (2021). COVID-19 and Post-pandemic Educational Policies in Mexico. What is at Stake?. In Primary and Secondary Education During Covid-19 (pp. 153-175). Springer, Cham. 
Chi, M. T., Siler, S. A., Jeong, H., Yamauchi, T., \& Hausmann, R. G. (2001). Learning from human tutoring. Cognitive science, 25(4), 471-533.

Dang, H. A., \& Rogers, F. H. (2008). The growing phenomenon of private tutoring: Does it deepen human capital, widen inequalities, or waste resources?. The World Bank Research Observer, 23(2), 161-200.

Dawson, W. (2010). Private tutoring and mass schooling in East Asia: Reflections of inequality in Japan, South Korea, and Cambodia. Asia pacific education review, 11(1), 14-24.

Drijvers, P., Thurm, D., Vandervieren, E., Klinger, M., Moons, F., van der Ree, H., ... \& Doorman, M. (2021). Distance mathematics teaching in Flanders, Germany, and the Netherlands during COVID-19 lockdown. Educational Studies in Mathematics, 108(1), 35-64.

Entrich, S. R. (2020). Worldwide shadow education and social inequality: Explaining differences in the socioeconomic gap in access to shadow education across 63 societies. International Journal of Comparative Sociology, 61(6), 441-475.

Heraty, C., McGlinchey, A., Mulligan, P., O'Hanrahan, P., O'Malley, J., O'Neill, R., \& Vivash, T. (2021). Technological Explorations in the Move to Online Mathematics Support. MSOR Connections, 19(1).

Jayachandran, S. (2014). Incentives to teach badly: After-school tutoring in developing countries. Journal of Development Economics, 108, 190-205.

Joseph, N. M., Frank, T. J., \& Elliott, T. Y. (2021). A call for a critical-historical framework in addressing the mathematical experiences of Black teachers and students. Journal for Research in Mathematics Education, 52(4), 476-490.

Johns, C., \& Mills, M. (2021). Online mathematics tutoring during the COVID-19 pandemic: Recommendations for best practices. Primus, 31(1), 99-117.

Krause, C. M., Di Martino, P., \& Moschkovich, J. N. (2021). Tales from three countries: reflections during COVID-19 for mathematical education in the future. Educational Studies in Mathematics, 1 -18.

König, J., Jäger-Biela, D. J., \& Glutsch, N. (2020). Adapting to online teaching during COVID-19 school closure: teacher education and teacher competence effects among early career teachers in Germany. European Journal of Teacher Education, 43(4), 608-622.

Lantsoght, E. O., Crepaldi, Y. T., Tavares, S. G., Leemans, K., \& Paig-Tran, E. M. (2021). Challenges and Opportunities for Academic Parents During COVID-19. Frontiers in psychology, 12, 645734.

Leyva, L. A. (2021). Black women's counter-stories of resilience and within-group tensions in the white, patriarchal space of mathematics education. Journal for Research in Mathematics Education, 52(2), 117-151.

Maloney, T., \& Matthews, J. S. (2020). Teacher Care and Students' Sense of Connectedness in the Urban Mathematics Classroom. Journal for Research in Mathematics Education, 51(4), 399-432.

Matthews, L. E., Jessup, N. A., \& Sears, R. (2021). Looking for "us": power reimagined in mathematics learning for Black communities in the pandemic. Educational Studies in Mathematics, 108(1), 333-350.

Mullen, C., Pettigrew, J., Cronin, A., Rylands, L., \& Shearman, D. (2021). Mathematics is different: student and tutor perspectives from Ireland and Australia on online support during COVID19. Teaching Mathematics and its Applications, 40(4), 332-355.

Natasha, C., Kyridis, A., \& Christos-Thomas, K. (2021). A view on the Greek shadow education at the era of the economic crisis. How do private tutors' working conditions are formed? European Journal of Education Studies, 8(3), 310-326.

Oliveira, G., Grenha Teixeira, J., Torres, A., \& Morais, C. (2021). An exploratory study on the emergency remote education experience of higher education students and teachers during the COVID-19 pandemic. British Journal of Educational Technology.

Pai, H. J., Ho, H. Z., \& Lam, Y. W. (2017). It Takes a Village: An Indigenous Atayal After-School Tutoring Program in Taiwan. Childhood Education, 93(4), 280-288.

Reimers, F. M. (2021). Primay and secondary education during Covid-19: disruptions to educational opportunity during a pandemic. Springer, Cham.

Rickard, B., \& Mills, M. (2018). The effect of attending tutoring on course grades in Calculus I. International Journal of Mathematical Education in Science and Technology, 49(3), 341-354.

Saldaña, J. (2013). The coding manual for qualitative researchers. Los Angeles: Sage.

Silova, I., \& Budiene, V. (2006). Education in a hidden marketplace: Monitoring of private tutoring. New York: Open Society Institute.

Silova, I. (2010). Private tutoring in Eastern Europe and Central Asia: Policy choices and implications. Compare, 40(3), 327-344.

Soudien, C., Reddy, V., \& Harvey, J. (2021). The impact of COVID-19 on a fragile education system: 
The case of south africa. In Primary and Secondary Education During Covid-19 (pp. 303-325). Springer, Cham.

Sulisworo, D., Nasir, R., \& Maryani, I. (2017). Identification of teachers' problems in Indonesia on facing global community. International Journal of Research Studies in Education, 6(2), 81-90.

Williams, S. R., \& Leatham, K. R. (2017). Journal quality in mathematics education. Journal for Research in Mathematics Education, 48(4), 369-396.

Wu, S. Y., \& Battey, D. (2021). The Cultural Production of Racial Narratives About Asian Americans in Mathematics. Journal for Research in Mathematics Education, 52(5), 581-614.

Yılmaz, Z., Dede, H. G., Sears, R., \& Nielsen, S. Y. (2021). Are we all in this together?: mathematics teachers' perspectives on equity in remote instruction during pandemic. Educational Studies in Mathematics, 1-25. 